\title{
The Heart and its Penetrations in Piers PLOWMan B
}

\section{Rosanne Gasse}

The Tree of Charity in passus 16 of Piers Plowman B is what one might call a "load-bearing" episode. It sets in motion the climatic redemptive action which builds up to Christ's victory over Satan and Death in passus 18, even as it anticipates the collapse of the Barn of Unity at the end of the poem. The Tree also looks back to much previous action within the text: the Castle of Kynde within which Anima resides under the protection of its Constable, Sir Inwit, and his five sons at the start of passus 9; Piers's half-acre in passus 6; Truth's courtly manor house at the end of the journey in passus 5; and Holy Church's metaphor-laden explication in passus 1 upon the Truth that is Love. The Tree of Charity episode branches out of and toward the entire poem, affecting its meaning in toto.

But understanding the opening movement of passus 16 is no easy task: Langland's image of the Tree growing in its heart garden is complexly metaphoric in that heart, tree, and garden are actual and yet figurative at the same time. The "ful trie" Tree of Charity " "growep in a gardyn,' quod [Anima], ' pat God made hymselue; / Amyddes mannes body pe more is of pat stokke. / Herte highte pe herber pat it inne growep"' (16.13-15). First, the image appeals to the multiple figurative associations of the noble heart. The heart, according to the thirteenthcentury medical writer Gilbertus Anglicus, is "pe principal membre of a mannes body." 2 It is an organ set within the interior space of the body cavity. Langland's image, however, also appeals to the equally complex figurations of the tree. ${ }^{3}$ Both a heart and a tree are physical objects foundational to everyday life, existing within a set, immovable space. In Piers's case, the Tree of Charity is located

\footnotetext{
${ }^{1} \mathrm{In} \mathrm{C}$ at this point, the speaker is clearly identified as Liberum Arbitrium (C.18.1). Who is speaking in B is much less certain. One must go all the way back to the start of passus 15 to find a character named as speaker: the multiply-named "sotil pyng ... wipouten tonge and teep" (B.15.12-13) which calls itself "Cristes creature" (15.16). Anima is the first of nine names this creature gives to identify itself at 15.23-39e. All references to Piers Plowman are from William Langland, Piers Plowman: A Parallel-Text Edition of the A, B, C, and Z Versions: Vol. I: Text, ed. A. V. C. Schmidt (London and New York: Longman, 1995). Citations are to the B version unless otherwise indicated.

${ }^{2}$ Faye Getz., ed., Healing \& Society in Medieval England: A Middle English Translation of the Pharmaceutical Writings of Gilbertus Anglicus (Madison, Wisconsin: University of Wisconsin Press, 1991), 143.

${ }^{3}$ The literature on the symbolism of trees in the medieval arts is vast. Two recent studies include The Tree: Symbol, Allegory, and Mnemonic Device in Medieval Art and Thought, ed. Pippa Salonius and Andrea Worm (Turnhout, Belgium: Brepols, 2014), and Rosanne Gasse, "The Dry Tree Legend in Medieval Literature,” Fifteenth-Century Studies 38 (2013): 65-96.
} 
within the specific interior space of an arboreal garden, a herber, a third object richly figured and a literal space that is functional rather than merely decorative. ${ }^{4}$

This paper approaches how the Tree of Charity episode intersects with the whole of Piers Plowman through close study of the human heart as a thematic motif within the text, especially as the motif evolves around larger visual concepts of penetration, interiority, and exteriority. Implicit in this penetrative cardiac imagery may be the trope of human hearts as opened books at Doomsday- "vivid emblems of the fully revealed inner self," as discussed by Eric Jager in The Book of the Heart. ${ }^{5}$ Perhaps also in play are the more literal connotations of the St. Ignatius of Antioch legend in which the saint's dead body was cut into, his heart removed and opened up to find the inscription in gold lettering "Ihesus Christus," or the image of the crucified Christ that was found in the dissected heart of St. Clare. ${ }^{7}$ Another implicit reference may be the subtle medical/theological notion of the heart as porous and full of invisible holes through which air and spirits could enter and exit as described by Heather Webb in The Medieval Heart. ${ }^{8}$ Nonetheless, Langland's text does not require readerly knowledge of remote allusions or of medicalized theology for its own plentiful cardiac imagery to signify his ultimate hopeful message. Langland's own penetrative imagery found in the Tree of Charity episode and throughout Piers ratifies his optimistic belief in the reciprocal thoroughness of God's connection to us, inside and out. In particular, cardiac penetration illustrates the multiply-figured close bond between human and divine, the bringing together through love of what has been broken apart and separated.

The human heart is located in the interior space of the human body, but the heart is an inner organ thought to possess an interior space of its own; something exists other than the obvious muscle and blood inside the hollow chambers of the medieval heart. What this something is and/or means varies according to author and text. The interiorized heart has many positive associations in medieval writing. Jager points out in The Book of the Heart that the heart was long believed to be a synonym for "thought, memory, mind, soul, and spirit as well as for the seat of intelligence, volition, character and the emotions." With respect to Piers Plowman, M. Teresa Tavormina in Kindly Similitude asserts that Langland

\footnotetext{
${ }^{4}$ The literature on the symbolism of gardens in the medieval period is equally vast. Some recent studies include Mailan S. Doquang, The Lithic Garden: Nature and the Transformation of the Medieval Church (Oxford: Oxford University Press, 2018); Amy Tigner, Literature and the Renaissance Garden from Elizabeth I to Charles II: England's Paradise (Farnham, Surrey: Ashgate, 2012); and Sarah Powrie's “A Moral Garden 'Oute of Olde Feldes': Deallegorized Virtue in Chaucer's Parliament of Fowls," Modern Philology 114 (2016): 170-94. For discussion of the garden connected to the Tree of Charity episode in Piers, see Ralph Hanna, "The Tree of Charity - Again," in Medieval Alliterative Poetry: Essays in honour of Thorlac Turville-Petre, ed. John A. Burrows and Hoyt N. Duggan, (Dublin: Four Courts Press, 2010), especially 128-35.

${ }^{5}$ Eric Jager, The Book of the Heart (Chicago: University of Chicago Press, 2000), 119.

${ }^{6}$ For the story of the heart of St. Ignatius, see the early fifteenth-century Middle English translation of the Legenda Aurea, The Gilte Legende: Vol. 1, ed. Richard Hamer (Oxford: Oxford University Press, 2006), 35.110-17.

${ }^{7}$ See Heather Webb's "short tour of holy dissected hearts" (including what was seen in St. Clare's) in The Medieval Heart (New Haven and London: Yale University Press, 2010), 172-77.

${ }^{8}$ Webb, The Medieval Heart, 50-51.

${ }^{9}$ Jager, The Book of the Heart, xv.
} 
equates the heart with the self, the fundamental source of the human creature's kynde knowing of its Creator. ${ }^{10}$ In The Place of God, Mary Clemente Davlin surveys various fourteenth-century views on the heart as a symbol, paraphrasing its centrality in Langland's text as "the place where love is learned [...] where the values of one's life are kept and remembered [...] the centre of sincerity or truth."11

The medieval moralists offer a contrary discourse on what one will find within the interior of the heart. In "The Eyes, the Heart and the Medieval Envy," Matthew Shoaf reveals that the moralist regards the heart's metaphoric value as a hollow interior space all too apt to be filled with the deadly sin of envy. According to the fourteenth-century Italian scholar Benvenuto da Imola, for example, the heart is envy's home, while Gregory the Great much earlier construed the heart as an empty vessel easily corruptible by the devil, who could pour into it "the poison of the ancient enemy." Basil of Caesaria likewise described the envious man pierced "to his heart's core with blows and wounds when he witnessed others' blessings." 12

This moralist tradition appears in Langland's text via Haukyn's confessed desire in passus 13 to hold maistrie over others. Although envy is not visualized here as explicitly penetrative, it certainly is, as da Imola points out, a vice centerd in the heart. Haukyn's desire for maistrie denotes his envy of others. Sometimes this desire is so strong that it causes Haukyn to experience the cardiacle (13.33435 ), which is a catchall term for symptoms of heart disease such as infarction, chest pains, and various types of irregular heartbeat, including leaping and trembling hearts as well as syncope. ${ }^{13}$ That Haukyn's yearning for maistrie in Piers has something to do with envy is proven by the earlier confession of the Deadly Sins in B passus 5, in which Envy twice expresses the desire to possess power over others, to be the master over all $(5.102,115)$. Indeed, in the $\mathrm{C}$ version, Langland transposes Haukyn's cardiacle episode from B passus 13 over to Envy's confession at C.6.77-78.

Moreover, the physical emphasis of Envy's description in his confession is upon serious heart disease. The first detail one learns through Envy's confession is that his heart is heavy (A.5.58; B.5.75; C.6.63), and then later he admits that a diapenidion (a pharmaceutical lozenge) cannot drive away the swelling from his heart (A.5.100-02; B.5.121-22; C.6.88-90). Envy's prominent and manifold stomach ailments, which are alluded to in all three versions of Piers, also connect Envy to heart disease because medieval medicine recognized that the health of these two organs was connected. According to Gilbertus Anglicus, for instance,

\footnotetext{
${ }^{10}$ M. Teresa Tavormina, Kindly Similitude: Marriage and Family in Piers Plowman (Woodbridge, Suffolk: D.S. Brewer, 1995), 113.

${ }^{11}$ Mary Clemente Davlin, The Place of God in Piers Plowman and Medieval Art (Aldershot: Ashgate, 2001), 104-05.

${ }^{12}$ All these references are found in Matthew Shoaf, "The Heart, the Eyes and Medieval Envy," Micrologus 11 (2003): 217-18. For further references, see also Virginia Langum, Medicine and the Seven Deadly Sins in Late Medieval Literature and Culture (New York: Palgrave MacMillan, 2017), 108.

${ }^{13}$ See Faye Getz's edition of the Middle English text of Gilbertus Anglicus for the definition of cardiacle, an explication of its various types and causes, and its range of treatments in the Middle Ages (Healing and Society, 143-53).
} 
one cause of the cardiacle is that "it comep of corrupt humours and kene pat ben in pe moup of pe stomake and goip vp to pe herte by smale veynes and greuep pe herte." ${ }^{14}$ Envy thus suffers not only from a swollen stomach but also from an aggrieved heart. Interior spaces, stomachs and hearts, intersect imagistically as well as literally. Langland's figuration joins the metaphoric with the embodied; the poem's poetic morals suggest that Envy's - and Haukyn's - cure is beyond the worldly and pharmaceutical.

While the moralist tradition has well established envy as a vice which enters the heart to corrupt the person from within, Langland also identifies pride as a cardiac sin. This particular connection of vice and bodily organ, however, is unusual for the time period. As Virginia Langum points out in Medicine and the Seven Deadly Sins, the moralists most often associate pride with diseases afflicting the head (madness, epilepsy, eye disease) and with swelling (inclusive of dropsy and leprosy). ${ }^{15}$ Yet in Piers, Langland centers pride in the heart. In the A and B versions, Langland gives Pride a mere nine lines, but packed within them are three references to the heart, one of which is embedded in Pride's name, Purnele Proud-herte. In her confession Purnele vows, "Shal neuere heiz herte me hente, but holde me lowe / And suffre to be mysseyd - and so dide I neuere. / But now wole I meke me and mercy biseche / For al pat I haue hated in myn herte" (B.5.67-70). As with Envy, Langland foregrounds interior cardiac action: Pride's hate is sourced, physically and metaphorically, in her heart. Furthermore, between the end of Pride's heart-filled confession and the beginning of Envy's heavyhearted speech — between the two cardiac sins of Envy and Pride - B interposes a scant four lines concerning the vice of Lechery, a closeness on the page which further suggests the minimal distance between the two cardiac sins. The $\mathrm{C}$ version, in comparison, extends the confession of Pride far beyond its otherwise meager nine lines, and Langland adds another cardiac reference to Pride when Pernelle Proudherte admits of herself that she has been "vnbuxum" and "nat abaschet to agulte / God and goode men, so gret was myn herte" (C.6.17-18). C further cements the bond between the two major sins of the heart by moving directly from Pride to Envy, postponing Lechery's expanded confession until after Wrath's speech. ${ }^{16}$ While neither vice in Piers penetrates narratively into the heart, Pride and Envy both must find their way into the heart, somehow or other, from outside the self. They are the weeds that enter from the outside and which then must be dug out of the heart garden by Liberum Arbitrium in passus 16 (16.17) and harrowed out of the soul soil by Piers in passus 19 (19.312-16). The heart, healthy

\footnotetext{
${ }^{14}$ Getz, Healing and Society, 143.

${ }^{15}$ Langum, 84-86.

${ }^{16}$ In $\mathrm{C}$, while pride and envy are the primary sins of the heart, three other vices have some cardiac association. Wrath has one direct reference (6.146) and Sloth another (7.17). The two cardiac references for Covetise, on the other hand, are very indirect in C. One is made by Repentaunce in his advice to Robert the ruyflare/vsurer at line 6.331 that his heart and tongue need to go in the same direction. The other occurs in the Latin quotation of Matt. 6:21 which, because it is placed at 6.285a between the end of Covetise's speech and the start of Repentaunce's shocked reply, is attributable to no clear speaker: "Vbi tezaurus tuus ibi et cor tuum" (your treasure is where your heart is). The location is deliberate in its lack of clear reference because the sentiment applies equally well to both Covetise and Repentance, albeit with diametrically opposed meanings as to the sort of tezaurus meant. In B, of the other five sins only Sloth has a cardiac reference, with the ambivalent Latin quotation of Matt. 6:21 associated with Covetise in C included instead as part of the Haukyn episode at B.13.399a.
} 
or diseased, is thus a potent symbol in its own right with many iterations throughout Piers to give its use as a figure in passus 16 a bountiful context.

Indeed, Langland's figuration of Charity as a fruit tree growing in the heart garden is itself a penetrative cardiac image. Actual trees do more than exist on the surface of the ground: they have roots. Like tree roots in the everyday world, the Tree of Charity's roots must penetrate deep down into the soil of the heart garden - an image combining tree, heart, and penetration. Above ground, unless vigorously kept cut back the Tree's branches will rise high up, certainly higher than any wall one might find around a small enclosed formal medieval garden or "herber" that acts as a figure for the heart in this episode. The heart herber, after all, is visualized in passus 16 as a garden open to the sky, a vantage point from which anything can move unobstructed in or out of the contained space below. No medieval herber would be set within a structure such as a glasshouse with a hard, confining roof limiting access inward and outward. Indeed, as Heather Webb reminds us, the medieval heart is defined by its porosity. ${ }^{17}$ Like the walled herber open-ended at its top, the heart not only has a set physical limit as a bodily organ, but all sorts of things, physical and metaphysical-including pride and envy-enter and exit the porous medieval heart. The heart, then, is an interior space with its own interior space, one that, with ripe imagery abounding, can be penetrated easily in either direction.

The poem alludes simultaneously to both figurative and literal penetration of the heart. Christ's heart was first visibly penetrated by the spear of Longeus (18.85), and then by the fingers of Doubting Thomas (19.170-72). His heart continues to be pierced abstractly by the arrows of profane oaths (20.225-26). A. V. C. Schmidt has observed that most visual depictions of the Crucifixion scene in art at this time show Longeus's spear entering Christ's side, a direction from which the sacred heart would be spared the lance's damaging thrust. ${ }^{18}$ Langland, however, unconventionally chooses to locate the entry point of Longeus's spear as aimed upward into Christ's body and explicitly into the heart (18.85), making visibly manifest the innate porosity of the sacred organ-which, like any heart, must share and breathe the same air and spirits as all other living creatures. Yet what Christ's opened, visibly-porous divine heart shares with the outside world is unique. As Schmidt argues, the vital life's blood that pours out of Christ's penetrated heart is both the literal sacrificial offering to propitiate humanity's sin and the figurative potential sacramental release from sin through baptism. ${ }^{19}$ Likewise, the upward force of momentum as the spear moves through the divine

\footnotetext{
17 "In order to fully explore the dominant conception of the porous, breathing heart [...], we must excavate the images that made the heart what it was in the medieval imagination, holes and all. This is not simply a problem of the details of the heart's anatomy. These porosities in the heart and openings in the arteries meant that each individual human heart was accessible to air from the outside world, or in other words that each individual person was open even to the very core of his or her being. The air that moved between people, as it moved between the earthly and the divine realms, could be imbued with spirits of all kinds, from the terrestrial purveyors of sensation to divine entities or even demonic creatures. Concepts and images of the porous heart were elaborated in religious texts and in poetry, shaping the ways in which people understood the relationship between their bodies and the external world." Webb, The Medieval Heart, 51.

${ }^{18}$ A. V. C. Schmidt, "The Sacramental Significance of Blood in Piers Plowman," in Medieval Alliterative Poetry: Essays in Honour of Thorlac Turville-Petre, ed. John A. Burrows and Hoyt N. Duggan (Dublin: Four Courts Press, 2010), 218.

${ }^{19}$ Schmidt, Sacramental Significance, 219.
} 
interior to push against the sacred heart within seems designed to recall the priest's calling out in the Preface of each Mass, "Sursum corda" (Lift up your hearts).

After being run through by a spear, however, any heart will be very much a broken and damaged internal organ. In Piers, Christ's distressed and broken heart reverberates in a series of textual moments centered on penetration, cardiac and otherwise, that are as involved and complex as any other motif in the poem and that connect meaningfully to the penetrative Tree of Charity episode. These reverberations range from an early reference in the poem to the soldiers who "pirled" Christ's heart as he hung high on the cross (A.1.148; B.1.174; C.1.169), to a second literal penetration of Christ's heart by the fingers of Doubting Thomas, invited to reach inside the chest wall and feel the fleshly heart of the risen Christ (19.170-72) and then, at the end of the poem, to those contemporary penetrations of God's heart shot through with metaphorical arrows of profane oaths (B.20.226).

The motif of penetration recurs more widely than the pierced sacred heart. The text contains reference to several implements designed to break through a surface: the pickaxe (3.309), the spade (3.309), the pick (6.103), the cultour (6.104), the hoe (16.17), the aithe [harrow] (19.273), and, of course, the plow (3.309). While all these penetrative tools exist as literal pieces of farming equipment, many of them also function significantly within the text on a figurative level. In passus 19, the harrow of the Old Law and the New Law penetrates into the ploughed soil of man's soul so that the grains of Grace may grow unimpeded there (19.312-16); in passus 16, Liberum Arbitrium penetrates the heart garden with a hoe to pick out the weeds (16.17); and, as Stephen A. Barney pointed out long ago in his seminal article "The Plowshare of the Tongue," the notion of the priest's tongue as a plowshare is a medieval commonplace. ${ }^{20}$ Indeed, the poem's piercing agricultural implements all derive their thematically sacred penetrative force from one of Holy Church's images to conceive of the Love-that-is-Truth. Love, which can pass through any man-made barrier, is as "portatif and persaunt as pe point of a nedle" (1.157) - the sharp tip of a piercing implement which is anticipatory of Longeus's spear, but reversed in agency and inverted in size and social status to become a tailor's, surgeon's, or woman's small tool instead of a large knightly weapon. ${ }^{21}$ In Holy Church's needle simile, divine Love is the agent of penetration and the human body the penetrated object, just as later in the text God will plant the Tree of Charity in the heart garden in passus 16 and as Piers will sow the four seeds of Grace into the soul soil in passus 19 "pat loue my3te wexe / Among pise foure vertues, and vices destruye" (19.313-14).

\footnotetext{
${ }^{20}$ Stephen A. Barney, "The Plowshare of the Tongue: The Progress of a Symbol from the Bible to Piers Plowman," Medieval Studies 35 (1973): 261-93.

${ }^{21}$ In like manner, Holy Church in the same passage anticipates the Tree of Charity and the Cross of the Crucifixion in her metaphor of Love as "pe plante of pees" (1.152). The reference to a "leef vpon lynde" at line 156 suggests that the plant intended is a linden-tree. Several other of Holy Church's metaphors reappear later in the poem also: love as the triacle of heaven (1.148) resurfaces as Christ's drink of love (18.366); love as the leader of the Lord's folk of heaven (1.159) anticipates Christ's triumphant leading of the souls of the righteous out of Hell and up into Heaven after the Harrowing (18.407); love as the intermediating mayor between the king and the commons (1.160) reflects Jesus Christ's dual nature as both man and God (19.15-68). Langland is indeed meticulous in drawing together the visual thematic motifs of his poem.
} 
However, not all cases of penetration in the text affirm the good nor enter into the heart specifically. The piercing arrows of profane oaths shot figuratively into God's heart in passus 20 belong to the envious and proud Pricker of France (9.7-8) - a penetrating name in and of itself. One of the Pricker's most effective agents is Sire Penetrans Domos, the friar with the piercing name who needs only the plowshare of his glib tongue to break through the defenses and enter into Unity (and its women). Sire Penetrans reiterates an ancient pattern: so Lucifer broke into the Garden of Eden (18.288); so the weeds Envy and Pride find their way into the heart garden and the soul soil. Holy Church's simile for Love as a humble needle and its later iterative figurations in the text stand against the aggressive and militaristic connotations of the evil Pricker and his piercing forces of destruction. Whereas the Pricker's spears, spurs, swords, battle-axes and arrows rupture and separate that which they run through, Love's humble sewing needle pierces in order to bring separate parts together, whether it be to create something new (as in tailoring) or to repair something old (as in darning, patching, or suturing). Love, that is, brings the human and the divine together and repairs the relationship damaged by the Fall. Yet as a poet Langland cannot resist word play with this visual concept of penetrative union skewered together like two pieces of meat, the eye(lid)s of Longeus are held shut and blind until the unspearing action of the blood of Christ removes the militaristic agents of penetration forcibly holding them together (B.18.86). ${ }^{22}$

The poem's imagery intersects pierced hearts and penetrated gardens. The divine heart is literally penetrated twice, first by Longeus and then by Thomas; the human heart is pierced by the Tree of Charity's roots. So, too, another familiar object of everyday life figuratively penetrates the human heart: a water well. Langland locates Love's head and high well within the human heart, which provides, as Holy Church says at 1.164, an endless source of refreshment that anticipates the constant outpouring of saving blood from Christ's heart. ${ }^{23}$ Any actual well, whether a natural artesian one such as St. Ann's Well set on the eastern slopes of the Malvern Hills above Great Malvern Priory and known to be in use by the 11 th century ${ }^{24}$ or a man-made construction, must penetrate deep into the ground to find the interior source of the life-giving liquid that can be drawn, either by natural positive pressure or by a bucket, to the surface. As a penetrative motif, then, the image reminds the reader that there is something fundamental and refreshing to be found down deep within the heart's Well of Love. Elsewhere, Temperance comes out of the Well of Wisdom (14.307), and Anima, self-defined as Sensus, draws wit and wisdom out of the Well of All Crafts (15.30). ${ }^{25}$

\footnotetext{
${ }^{22}$ See my discussion of the spearing and unspearing of Longeus's eye(lid)s in "Reneying the Reneyed: Language Play, Eyesight, and Salvation in Piers Plowman," Enarratio 17 (2010), especially at $44-45,47$.

${ }^{23}$ Davlin, The Place of God, 71. Love's well penetrating the heart, of course, is yet another case of a metaphor found in Holy Church's speech which resurfaces later in the text in an altered form, this time as the Tree of Charity growing in the heart garden.

${ }^{24}$ Some basic historical information on St. Ann's Well in Malvern can be found at http://www.malvernwaters.com/nationalparks.asp? search=yes\&p=7\&id=327.

${ }^{25}$ Langland is not specific as to what sort of well he wants his reader to imagine. It could, therefore, be visualized as a well dug by human hands into a source of water underground which must then be brought to the surface by manual labor, or as an artesian well in which the water rises up to the surface
} 
In cardiac terms within Piers, the interiority suggested by trees and wells penetrating downward into the heart appears as the metaphoric end point toward which these images allegorically reach: the location where someone is found inside the heart. Such allegory may recall the moralist's fear of the weedy, cardiac Envy (or Pride) lurking within the heart, but Langland upends the moralist's gloomy expectation because, in his text, the heart's space is already occupied by the Truth-that-is-Love; the enemy can therefore only exist and plot from outside its walls. Envy should not be able to enter and poison the heart-well as Gregory the Great feared - unless someone on the inside lets the vice in. Unfortunately, in the catastrophic last passus of the poem, the residents of the Barn of Unity will open their doors to the piercing agent Sire Penetrans, a friar sent by the cardiac sin Envy to study philosophy at school (B.20.295-96). ${ }^{26}$ But in the earlier passus 16 , the heart garden proves resistant to invasion: its interior space is taken up by the roots of the Tree of Charity, "Trewe-loue" as the tree is named in C at 18.9. While the Enemy can climb on a ladder and steal some of the fruit from the outside, the Tree's mobile defenders, Piers Plowman and Liberum Arbitrium, stand firmly on guard and the Tree itself is "vnderpizt" with three wooden posts to support the weight of its branches against damaging winds (B.16.23-25). ${ }^{27}$ Liberum Arbitrium, moreover, diligently picks out any weeds that may try to take root (B.16.17). Even earlier, in passus 5, Piers tells his prospective fellow travellers that at journey's end they will find that Truth sits in their hearts (5.606). ${ }^{28}$ The heart is the well-kept home of the Truth-that-is-Love; the catastrophe of the last passus need not happen.

If Truth and Love, the rightful occupants of the heart, displace the cardiac Envy and Pride, the concrete language of inward journey and interior location discursively returns the reader to cardiac penetration: to sit inside the chambers of the human heart, the outsider Truth must be placed there, an act which implicitly entails an interior penetration of both body and heart. The same penetrative interiority is true of Anima. Her refuge is in the heart (9.56), but to reach that point of safety she must penetrate its fortress walls. The Tree of Charity's heart garden - the herber - triply metaphorizes penetration. The first interiorizing act breaks into the heart to plant the seed or seedling there, and then, in a second interiorizing act, the Tree's roots, like Love's well, penetrate deep and downward as they grow ever further into the heart. The third is the exteriorizing act through which the Tree grows up and out of the heart in the visibly social acts of kindness,

under its own pressure. While either type is possible, the artesian well better fits Langland's concept of water/blood flowing outward. Artesian wells can be natural springs or man-made.

${ }^{26}$ As Unity's fate demonstrates, Langland does not reject the moralists' fears about Envy's malevolent effect upon the interior, but he transfers the image from entrance into the heart to the penetration of the Barn instead.

${ }^{27}$ The details are symbolic: the three wooden supports represent the Trinity, while the damaging winds are the World, the Flesh, and the Devil. The props function also as weapons which Piers Plowman and Liberum Arbitrium wield against those who would steal the fruit of the tree.

${ }^{28} \mathrm{In} \mathrm{C}$ at this point, Piers goes on to predict that the discovered Truth will "charge Charite a churche to make / In thyne hole herte, to herborwe alle trewe / And fynde all manere folk fode to here soules" (C.7.256-58) in yet another anticipation of the later Tree of Charity and the Barn of Unity episodes. 
mercy, and obedience required of charitable living in the world. ${ }^{29}$ Patience's own appeal to the penetrative well image asserts that the exterior actions of satisfaction through prayers, penance, pilgrimage and charitable donation are useless unless they spring out of the Well of True Repentance (14.198). So, too, the Tree's outer social acts and its three ways of living in the world articulated by its fruits must, to have value, come from out of that genuine source lying deep within the heart, touched by the roots of the Tree. These four metaphors of cardiac penetrationLove's well, Truth's seat within, Anima's interior refuge, and the Tree of Charity - all metaphorically repeat Holy Church's original penetrative image of Love's portable and piercing needle point. ${ }^{30}$

Piercing and cardiac metaphors adumbrate the Longeus episode in passus 18, joining divine and literal narratives. Not only is Christ's heart pierced by the agency of Longeus's wooden spear, but Longeus's own body becomes subject to penetration. The exteriorizing blood of Christ exceeds the outer bounds of His heart and chest wall and simultaneously exits under pressure both outward (like Love as an artesian well or the Tree beyond the height of its garden's wall) and downward via the wooden spear (like Love's well and the Tree's roots) into Longeus's eyes, curing his blindness. Moreover, in passus 18, the probing fingers of Doubting Thomas repeat the pattern. Like the lance, Thomas's fingers, following the trajectory opened internally by the spear, enter the divine body's cavity to reach and feel the heart, but they also enter the porous divine heart to touch and feel the interior Truth living within: Christ's heart's resident, bulwark against envy or pride. Just as the spear acts as a double agent, enabling interior penetration of both the divine heart of Christ and the human eyes of Longeus, so too the fingers of Thomas entering the body of Christ can conduct His blood to human skin. The mutuality of penetration in these episodes-metaphoric, literal, and heart-centered-signifies the close bond between human and divine, the sewing needle bringing together what has been separated, the unspearing action which opens up the locked gates of heaven to the redeemed.

A final example demonstrates Langland's meaning-laden imagistic play with notions of cardiac penetration. In passus 11 , a mysterious voice-perhaps

\footnotetext{
${ }^{29}$ The episode as treated in $\mathrm{C}$ is even more emphatically penetrative. In addition to the interior intrusion into the herber to plant the tree there and the implicit recognition that tree roots grow downward into soil and the exterior act of the tree's branches and fruit growing up and outward, C includes also Liberum Arbitrium and the Dreamer penetrating "into a contre, Cor-hominis hit heihte" at C.18.4 to visit the Tree. The Tree, moreover, is pointedly said to be "an ympe" at 18.6, which means that its own physical boundaries were breached when a graft branch (Ymago-Dei) was implanted into it. Finally, by explicitly recognizing at this point the tree's fruit as "Cristes oune fode" at 18.14, the text reminds us that because food is meant to be eaten, the exteriorizing fruit should itself someday enter into the body of its consumer - a eucharistic message. In B, of course, Liberum Arbitrium's job is "to piken [the land] and to weden it" under the supervision of Piers Plowman (16.16-17), thus adding another penetrative touch to the text.

${ }^{30}$ Although Derek Pearsall's commentary in his New Annotated Edition of the C-text (Exeter: University of Exeter Press, 2008) focuses on the equivalent C-text passage at 1.153, his note on p. 64 is valuable for understanding B's line also: "The mobile activity and penetrativeness of love relates to the description of Wisdom in the apocryphal Book of Wisdom 7:22-24, to patristic commentary on the 'needle' of Luke 18:25, and to the image of the word of God as 'living and active, more piercing (penetrabilior) than any two-edged sword', in Heb. 4:12."
} 
Trajan, or, depending on how one parses the scene, some other unknown interjector-proclaims that the healthy heart is a kynde heart:

"For oure ioye and oure iuele, Iesu Crist of heuene,

In a pouere mannes apparaille pursuep vs euere,

And lokep on vs in hir liknesse and pat wip louely chere,

To knowen vs by oure kynde herte and castynge of oure eizen,

Wheiper we loue pe lordes here bifore oure Lord of blisse." (11.184-88)

Kynde, of course, is one of Piers Plowman's most slippery and complex terms. ${ }^{31}$ At the poem's outset, in the first passus, Holy Church explains that it is a kynde knowing that instructs the human heart (1.142), and then again that "in kynde knowynge in herte per comsep a myghte" (1.165). In passus 9, Kynde is the lover of Anima who resides within Kynde's heart-castle for her own protection, plus Kynde is rival to the envious, proud Pricker of France. The castle scene anticipates the climatic confrontation between Christ and Satan in the redemptive action of passus 18. In passus 11, however, Langland reverses the locations of kindness and knowledge: humans are the kynde ones, and the divine needs to know. Indeed, God needs "To knowen vs by oure kynde herte" (11.187). This reversal of location in its own way returns the discourse to cardiac penetration, because God knows us by our kind hearts and eyes, implicitly entering into the chest through the gateway of the eyes in order to look and discover who or what is hidden there inside our porous hearts.

Langland thus develops throughout his poem profoundly complex and intersecting metaphors of the heart and its penetrations that rise to the surface in the Tree of Charity episode both to coalesce and to spread out. Pernele Proudherte's great and high heart, lifted up to herself and not unto God, together with the swollen, heavy heart of Envy, betoken how damaged/damaging these cardiac vices are as/to human beings. In contrast, the penetrated heart becomes a positive sign through the heart of Christ, which is thirled on the Cross, ruptured by the spear of Longeus, and groped by the fingers of Thomas, all actions which bring the divine into close and redemptive contact with humanity. Likewise seen in its various and multiple figures of cardiac penetration and associated piercings, the humble human heart can strive to enact the kynde knowing that would bring it closer to God. Through his imagery of penetration of the heart garden, Langland intones a deeply optimistic counterpoint to what might seem the overwhelming pessimistic note upon which the poem concludes. The Barn of Unity need not fall to the penetrative and weedy forces of sin and evil, of pride and envy. Humans need only allow the divine presence to pierce us like a needle for Love to thrive and grow within our hearts and then reach its branches back up to God.

\section{Brandon University}

\footnotetext{
${ }^{31}$ For recent discussion of the polyvalent meanings of kynde in Langland's text, see particularly Rebecca Davis's sensitive reading throughout in Piers Plowman and the Books of Nature (Oxford: Oxford University Press, 2016), especially 2-34 and 240-44.
} 
Bibliography

Barney, Stephen A. "The Plowshare of the Tongue: The Progress of a Symbol from the Bible to Piers Plowman.” Medieval Studies 35 (1973): 261-93. https://doi.org/10.1484/J.MS.2.306140

Davis, Rebecca. Piers Plowman and the Books of Nature. Oxford: Oxford University Press, 2016.

https://doi.org/10.1093/acprof:oso/9780198778400.001.0001

Davlin OP, Mary Clemente. The Place of God in Piers Plowman and Medieval Art. Aldershot: Ashgate, 2001.

Doquang, Mailan S. The Lithic Garden: Nature and the Transformation of the Medieval Church. Oxford: Oxford University Press, 2018. https://doi.org/10.1093/oso/9780190631796.001.0001

Gasse, Rosanne. "The Dry Tree Legend in Medieval Literature." FifteenthCentury Studies 38 (2013): 65-96.

—. "Reneying the Reneyed: Language Play, Eyesight, and Salvation in Piers Plowman." Enarratio 17 (2010): 37-57.

Getz, Faye Marie, ed. Healing \& Society in Medieval England: A Middle English Translation of the Pharmaceutical Writings of Gilbertus Anglicus. Madison, Wisconsin: University of Wisconsin Press, 1991.

Hamer, Richard, ed. The Gilte Legende: Vol. 1. Early English Text Society o.s. 327. Oxford: Oxford University Press, 2006.

Hanna, Ralph. "The Tree of Charity - Again." In Medieval Alliterative Poetry: Essays in honour of Thorlac Turville-Petre, edited by John A. Burrows and Hoyt N. Duggan, 125-39. Dublin: Four Courts Press, 2010.

Jager, Eric. The Book of the Heart. Chicago: University of Chicago Press, 2000.

Langum, Virginia. Medicine and the Seven Deadly Sins in Late Medieval Literature and Culture. New York: Palgrave MacMillan, 2017. https://doi.org/10.1057/978-1-137-44990-0

Langland, William. Piers Plowman: A New Annotated Edition of the C-text. Edited by Derek Pearsall. Exeter: University of Exeter Press, 2008.

Langland, William. Piers Plowman: A Parallel-Text Edition of the A, B, C, and Z Versions, Volume I: Text. Edited by A. V. C. Schmidt. London and New York: Longman, 1995.

Powrie, Sarah. “A Moral Garden 'Oute of Olde Feldes': Deallegorized Virtue in Chaucer's Parliament of Fowls.” Modern Philology 114 (2016): 170-94. https://doi.org/10.1086/687326

Salonius, Pippa, and Andrea Worm, eds. The Tree: Symbol, Allegory, and Mnemonic Device in Medieval Art and Thought. Turnhout, Belgium: Brepols, 2014. https://doi.org/10.1484/M.IMREB.6.09070802050003050408030905 
Schmidt, A. V. C. "The Sacramental Significance of Blood in Piers Plowman." In Medieval Alliterative Poetry: Essays in Honour of Thorlac Turville-Petre, edited by John A. Burrows and Hoyt N. Duggan, 212-24. Dublin: Four Courts Press, 2010.

Shoaf, Matthew. "The Heart, the Eyes and Medieval Envy." Micrologus 11 (2003): 213-28.

Tavormina, M. Teresa. Kindly Similitude: Marriage and Family in Piers Plowman. Woodbridge, Suffolk: D.S. Brewer, 1995.

Tigner, Amy. Literature and the Renaissance Garden from Elizabeth I to Charles II: England's Paradise. Farnham, Surrey: Ashgate, 2012.

Webb, Heather. The Medieval Heart. New Haven and London: Yale University Press, 2010. 